\title{
Thermal parameters changes in males of Rhinella arenarum (Anura:Bufonidae) related to reproductive periods
}

\author{
Eduardo Alfredo Sanabria \& Lorena Beatriz Quiroga \\ Departamento de Biología, Facultad de Ciencias Exactas, Físicas y Naturales, Universidad Nacional de San Juan, \\ Avenida Ignacio de la Roza 590 (O), Código Postal 5400, Argentina; sanabria.eduardoa@gmail.com, \\ quiroga_lore@yahoo.com.ar
}

Received 20-V-2010. Corrected 30-IX-2010. Accepted 29-X-2010.

\begin{abstract}
The regulation of body temperature in ectotherms has a major impact in their physiological and behavioral processes. Observing changes in thermal parameters related with reproduction allows us to better understand how Rhinella arenarum optimizes a thermal resource. The aim of this study was to compare the thermal parameters of this species between breeding and non-breeding periods. In the field, we recorded the body temperature from captured animals, the air temperature, and the temperature of the substrate. In the laboratory, we measured the temperature $R$. arenarum selected on a thermal gradient and the critical extreme temperatures. The results of our study show variations in thermal parameters between the two situations studied. This species makes efficient use of thermal resources during the breeding period by basking to significantly increase body temperature. Because calling is energetically costly for males, this behavior results in increased efficiency to callers during the breeding period. Rev. Biol. Trop. 59 (1): 347-353. Epub 2011 March 01.
\end{abstract}

Key words: Argentina, Rhinella arenarum, thermal extremes, selected temperature, reproduction.

The regulation of body temperature in ectotherms has a major impact on their physiological and behavioral processes (Angilletta 2009). Body temperature in amphibians regulates a wide range of physiological processes including several aspects of male calls (Navas 1996, Pough et al. 2001), determining the pulse rate and the correlation with temperature (Zweifel 1968, Schneider \& Sinsch 1992, Luddecke \& Sánchez 2002).

In species such as Lithobates catesbeianus (Bee 2002) or Rana clamitans (Wells 1977b), males actively defend areas that have favorable nesting conditions (Brown 1964, Wells 1977a) or defend important resources for females or tadpoles (Pough et al. 2001). In species with prolonged breeding season such as Hyla versicolor or Pseudacris crucifer, the males defend the calling place. Because the energy for territory defense is thermo-dependent, these different cases of territorial behavior imply a mobility reduction via an energy budget tradeoff (Fellers 1979, Marshall et al. 2003).Therefore, a change in the strategy to obtain thermal energy is to be expected.

Some amphibians have a wide adaptability to thermal environmental changes (Brattstrom 1979), situation that demands a balance between body temperature and hydrological dynamics (Tracy 1976). In some cases this balance is compensated by the change of diurnal to nocturnal activity (Dullman \& Trueb 1986).

In the study area, $R$. arenarum, presents two reproductive events per year, in August and November (Sanabria et al. 2005a), during the reproductive period toads have a mean body temperature of $20^{\circ} \mathrm{C}$ (Sanabria et al. 2005b). The aim of this work was to compare thermal parameters of males of $R$. arenarum in the field 
and in the laboratory, during breeding and no breeding periods.

\section{MATERIALS AND METHODS}

The present work was carried out in the Zonda Department, San Juan province, Argentina (31.55 S; $68.70 \mathrm{~W}$; Datum WGS 84, elevation $650 \mathrm{~m})$. The fieldwork was conduced from August 10 of 2007 to February 20 of 2008. All determinations of temperatures in the laboratory were recorded in August to November 2007 as the breeding period (BP), and from December 2007 to February 2008 as the nonbreeding period (NBP). We collected 26 males by hand, 16 were collected during the breeding and 10 during the non-breeding period.

Body temperature was recorded with a digital thermometer TES 1312 (TES Electrical Electronic Corp., Taipei, Taiwan, $\pm 0.1^{\circ} \mathrm{C}$ ) immediately after capture, by inserting the thermocouple in the toad cloaca. Air temperature was recorded (TES TPK02 gas probe) at $1 \mathrm{~cm}$ over substrate and the substrate temperature was measured for direct contact of thermocouple (TES TPK03 substrate probe). The microenvironment temperature (mET) was determined by the mean between the air temperature and the substrate temperature. The data was recorded for each captured toad. The body length (snout-vent length; SVL) were measured with digital calipers $(0.01 \mathrm{~mm}$ precision).

Determination of selected temperature $\left(T_{\text {sel }}\right)$ : After being captured, toads were transferred to the laboratory and placed in open-top terraria $(120 \mathrm{~cm}$ long x $60 \mathrm{~cm}$ wide $\times 40 \mathrm{~cm}$ height), which was divided in four $15 \mathrm{~cm} \mathrm{x}$ $14 \mathrm{~cm}$ height compartments, to avoid interactions between neighboring animals (Light 1966). The terrarium had a linear thermal gradient, generated by a heat source underneath one end of the metallic floor. The warm side of the gradient was heated from $30 \mathrm{~cm}$ above with an electric resistance $(400 \mathrm{~W})$, and the temperature was controlled with a digital thermostat (AG, model TC-120L, San Juan, Argentina) to maintain a smooth thermal gradient ranging from 19.0-49.0 $\left( \pm 2.0^{\circ} \mathrm{C}\right)$. To avoid organism dehydration, the terrarium floor was covered with a moistened cotton cloth (water without chlorine). The $T_{\text {sel }}$ was determined by placing the frogs in a time gradient, from 09:30-18:30h. We recorded body temperatures $\left(T_{\mathrm{b}}\right)$ each hour. The $T_{\text {sel }}$ was considered as the average temperature recorded for each hour. A $T_{\text {sel }}$ was determined for each toad.

Determination of the critical thermal maximum $\left(\mathbf{C} \mathbf{T}_{\max }\right)$ and minimum $\left(\mathbf{C} \mathbf{T}_{\text {min }}\right)$ : The $\mathrm{CT}_{\max }$ and $\mathrm{CT}_{\text {min }}$ were determined by Hutchinson method (1961). For $\mathrm{CT}_{\max }$ the toads were placed in the glass with $300 \mathrm{~mL}$ of water at environmental temperature. An electrical heating mantle raised the temperature about $1^{\circ} \mathrm{C}$ per minute. For determination of the $\mathrm{CT}_{\text {min }}$ we placed the toads in the glass with $300 \mathrm{~mL}$ of water at environmental temperature. We placed the glass inside a plastic box with water, and the ice decreased the temperature about $1{ }^{\circ} \mathrm{C}$ per minute. The righting reflex was checked at regular intervals by turning the toads on their backs. If the righting reflex was lost, its body temperature was recorded and we considered this temperature as the $\mathrm{CT}_{\max }$ and $\mathrm{CT}_{\min }$.

Determination of warming rate (WR) and cooling rate $(\mathrm{CR})$ : $\mathrm{WR}$ and $\mathrm{CR}$ was calculated using the following equation: (warming or cooling rate $=\left(\mathrm{T}_{0}-\mathrm{T}_{\mathrm{F}}\right) / \mathrm{t} * \mathrm{SVL}$ ) where: $\mathrm{T}_{0}=$ initial body temperature $\left({ }^{\circ} \mathrm{C}\right) ; \mathrm{T}_{\mathrm{F}}=$ Final body temperature $\left({ }^{\circ} \mathrm{C}\right) ; \mathrm{T}=$ required time to pass from $\mathrm{T}_{0}$ to $\mathrm{T}_{\mathrm{F}}$ (seconds) and $\mathrm{SVL}=$ Snout Vent Length $(\mathrm{mm})$. For calculating the WR, initial temperature was laboratory temperature $25 \pm 2^{\circ} \mathrm{C}$ and the final body temperature was the $\mathrm{CT}_{\text {max }}$. For calculating CR the initial temperature was laboratory temperature $25 \pm 2^{\circ} \mathrm{C}$ and the final body temperature was the $\mathrm{CT}_{\text {min }}$.

All toads were released at the end of laboratory experiments. We used descriptive statistical analysis (mean \pm standard error). For comparison between breeding and non-breeding period we used Mann Whitney test. We use 
the PAST version 2.03 (Hommer et al. 2001) statistical free software for data analysis.

\section{RESULTS}

During BP we recorded thermal data of 16 toads $(\mathrm{SVL}=9.7 \pm 0.16)$ and $10(\mathrm{SVL}=$ $9.8 \pm 0.11)$ in NBP. The environmental temperature reported significant differences between BP and NBP (Mann Whitney, $\mathrm{U}=33, \mathrm{P}<0.01$ ), resulting higher in NBP. The $T_{\text {sel }}$ does not registered significant differences between $\mathrm{BP}$ and NBP ( $>>0.07)$; but the $T_{\mathrm{b}}$ was significantly different between BP and NBP (Mann Whitney, $\mathrm{U}=42, \mathrm{p}<0.04)$, being NBP higher. During BP not significant differences were detected between $T_{\mathrm{b}}$ and $\mathrm{mET}$ (Sing Test: $\mathrm{Z}=1.25$, p> 0.21 ); in other hand, the $T_{\mathrm{b}}$ was significantly different from the mET during NBP (Sing Test: $\mathrm{Z}=2.84, \mathrm{p}<0.004)$.
The $\mathrm{CT}_{\max }$ was significantly higher for the BP (Mann Whitney, $\mathrm{U}=19.5, \mathrm{p}<0.002$ ), and the $\mathrm{CT}_{\min }$ was significantly lower for BP (Mann Whitney, $\mathrm{U}=10, \mathrm{p}<0.0002$ ). The thermal range shows differences between $\mathrm{BP}$ and NBP (Mann Whitney, U=66, p< 0.0003), being higher in BP (Fig. 1). The warming rate was significantly different (Mann Whitney, $\mathrm{U}=$ $37, \mathrm{p}<0.02)$ for the BP, but the cooling rate did not showed differences $(\mathrm{p}>0.36)$ between both situations (Fig. 2).

\section{DISCUSSION}

Our results show that $R$. arenarum exhibits a narrow range of $T_{\text {sel }}$ despite changes in temperature during BP and NBP. Also, we found $T_{\mathrm{b}}$ to be different among periods; during BP, toads maintain a higher $T_{\mathrm{b}}$ than they do during NBP. The thermal tolerance range (Pough et al. 2001) was different between periods; during

TABLE 1

Thermal variables obtained in the laboratory and in the field, for the two periods: non-breeding and breeding

\begin{tabular}{|c|c|c|c|c|}
\hline & Variable & Mean & E.E. & Unit \\
\hline \multirow[t]{8}{*}{ Non-breeding period } & $T_{\mathrm{b}}$ & 22.58 & 0.57 & ${ }^{\circ} \mathrm{C}$ \\
\hline & $\mathrm{T}_{\text {sel }}$ & 26.48 & 0.48 & ${ }^{\circ} \mathrm{C}$ \\
\hline & $\mathrm{CT}_{\max }$ & 35.79 & 0.47 & ${ }^{\circ} \mathrm{C}$ \\
\hline & WR & 0.15 & 0.03 & ${ }^{\circ} \mathrm{C} / \mathrm{cm} * \mathrm{~s}$ \\
\hline & $\mathrm{CT}_{\min }$ & 5.37 & 0.20 & ${ }^{\circ} \mathrm{C}$ \\
\hline & $\mathrm{CR}$ & 0.06 & 0.01 & ${ }^{\circ} \mathrm{C} / \mathrm{cm}^{*} \mathrm{~s}$ \\
\hline & Range & 30.42 & 0.52 & ${ }^{\circ} \mathrm{C}$ \\
\hline & $\mathrm{mET}$ & 26.09 & 22.3 & ${ }^{\circ} \mathrm{C}$ \\
\hline \multirow[t]{8}{*}{ Breeding period } & $T_{\mathrm{b}}$ & 24.12 & 0.90 & ${ }^{\circ} \mathrm{C}$ \\
\hline & $\mathrm{T}_{\text {sel }}$ & 24.87 & 0.51 & ${ }^{\circ} \mathrm{C}$ \\
\hline & $\mathrm{CT}_{\max }$ & 37.48 & 0.21 & ${ }^{\circ} \mathrm{C}$ \\
\hline & WR & 0.08 & 0.01 & ${ }^{\circ} \mathrm{C} / \mathrm{cm}^{*} \mathrm{~s}$ \\
\hline & $\mathrm{CT}_{\min }$ & 4.39 & 0.08 & ${ }^{\circ} \mathrm{C}$ \\
\hline & $\mathrm{CR}$ & 0.05 & 0.002 .7 & ${ }^{\circ} \mathrm{C} / \mathrm{cm} * \mathrm{~s}$ \\
\hline & Range & 33.09 & 0.19 & ${ }^{\circ} \mathrm{C}$ \\
\hline & $\mathrm{mET}$ & 22.3 & 0.79 & ${ }^{\circ} \mathrm{C}$ \\
\hline
\end{tabular}

$T_{\mathrm{b}}=$ thermal body recorder in the field, $\mathrm{T}_{\text {sel }}=$ average of the temperate obtain in the linear thermal gradient; $\mathrm{CT}_{\max }=\mathrm{critical}$ thermal maximum; $\mathrm{WR}=$ warming rate; $\mathrm{CT}_{\min }=$ critical thermal minimum; $\mathrm{CR}=$ cooling rate; Range $=$ thermal range; $\mathrm{mET}$ = micro environmental temperatures. 


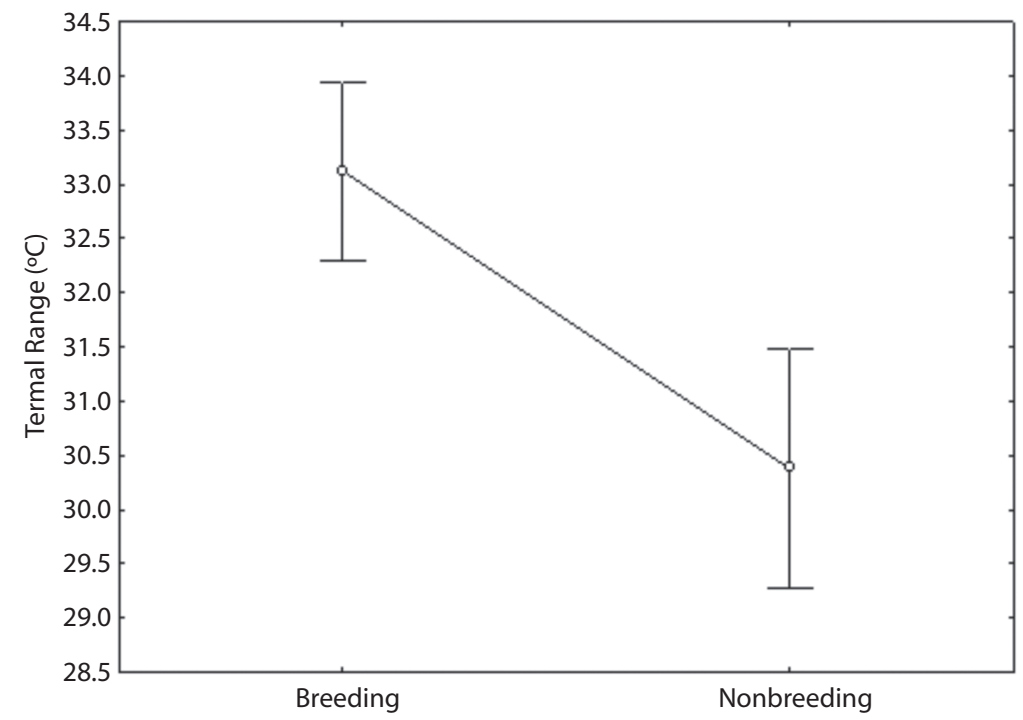

Fig. 1. Variation in the thermal range, for the two periods, breeding and non-breeding.

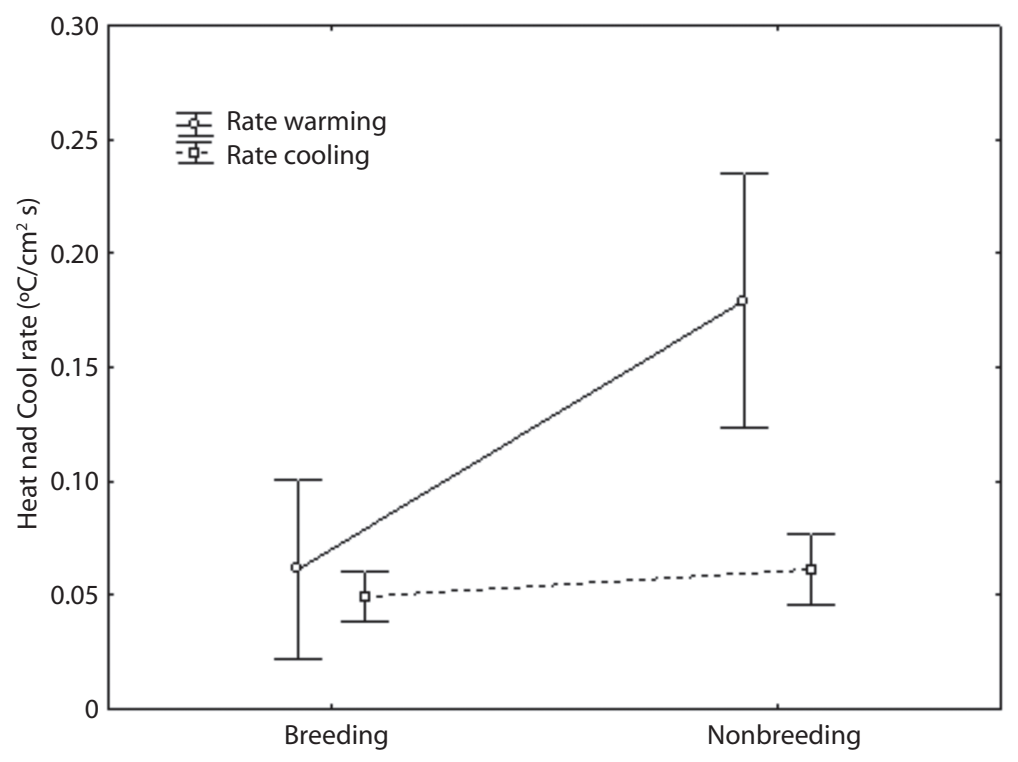

Fig. 2. Variation in the warming rate and cooling rate. The warming rate shows significantly differences $(p<0.02)$ between breeding and non-breeding periods.

$\mathrm{BP}$ the range was higher than in NBP. The thermal tolerance range is related to the availability of thermal energy in the microenvironment and the adaptability of the toads (Huey \& Stevenson 1979), because thermoregulation in amphibians is largely behavioral (Brattstrom 1963). The thermal tolerance range is limited by the thermal extremes, $\mathrm{CT}_{\text {max }}$ and $\mathrm{CT}_{\text {min }}$ (Pough et al. 2001). During BP, toads show an elevated $\mathrm{CT}_{\max }$. The elevated values recorded 
for this parameter have a direct relationship with the basking behaviour (diurnal activity) of the toads. The lower $\mathrm{CT}_{\min }$, values are a consequence of low environmental temperatures at night. The thermal range recorded for the breeding period is broader than the non-breeding period. Apparently, during BP the toads show acclimatization to the environmental temperatures, since the toads used all the temperatures available in the environment. Amphibians are organisms with a high plasticity regarding body temperature; whereby their ability to acclimate allows them to move between extreme thermal gradients (Brasttstrom \& Lawrence 1962). We found the thermal gain to be significantly slower during BP than during NBP. This slower warming rate may be attributed to their calling behavior, since during BP they call while in the water. It is possible that the toads less water through the skin freely during the BP since call inside the water, being the warming rate slower.

Basking is well known in some frogs (Rana mисоsa, Rana septentrionalis), but these frogs bask either partially submerged in water or on moistened substrates (Bradford 1984, Heeden 1975). During this period, water is not a limiting resource and toads select adequate temperatures to obtain a maximal performance (Tracy et al. 1993).

During the non-breeding period, the availability of water for $R$. arenarum is limited and toads have to walk further to reach habitats with suitable moisture levels (Sanabria et al. 2005a). Cutaneous transpiration is the principal mechanism that diminishes body temperature in amphibians (Spight 1967, Johnson 1971, Tracy 1976, Sinsch 1989, Shoemaker et al. 1992). Toads search for food during the night and select low temperatures in order to avoid water loss. In the case of Bufo americanus, different moisture conditions of the ground control the animals' temperature (dry ground results in lower body temperatures than wet ground) (Tracy et al. 1993).

The cooling rate of $R$. arenarum does not vary between reproductive and non-reproductive seasons. A possible cause for this is that amphibians do not generate metabolic heat to avoid this thermal loss (Brattstrom 1963).

The change in activity of $R$. arenarum (nocturnal to diurnal) during the reproductive period implies a thermal benefit that allows the toads to increase call performance. The call is strongly related to the body temperature (Duellman \&Trueb 1986, Wells 2001). During $\mathrm{BP}$, the principal activity of male toads is to call for females. While spending long periods of time calling, mobility is reduced and obtaining food is more difficult. Quiroga (pers. comm.) observed that during reproductive periods toads have prolonged fasts, in which the stomach contains only their own skin. In others bufonid toads, this behavior (ingesting their own skin) is well known and is apparently related with energy budget (Weldon et al. 1993). Although feeding is scarce during the reproductive period of $R$. arenarum, it appears that there is a physiological or behavioral mechanism that allows the adjustement of the optimum thermal range for reproduction. It is possible that $R$. arenarum uses stored fat, as do Elachistoclaeis bicolor, Rhinella fernandezae, and Leptodactylus latinasus. In these species, evidence shows an inverse relationship between the somatic index of the testicles and amount of body fat (Martori et al. 2005). Females prefer males with greater total sound energy in terms of calling rate, call duration, and loudness (Gerhardt 1994, Schwartz 2001). These attributes of calling activity impose a high energetic cost for male toads (Wells 2001). In this framework, $R$. arenarum gains energy from the environment during the day (basking for calling), to compensate for these energetic costs and to ultimately increase reproductive success.

\section{ACKNOWLEDGMENTS}

We give special thanks to Daniel Flores and Guillermo Ripalta for their help in the field, Juliana Nates and Jason Warner for the English review, and Myriam Iturra Cid for the helpful comments that improved this manuscript. We thank the Provincial Fauna Office of San Juan for permission to conduct our 
research. This research was partially supported by a graduate fellowship from CICITCA-UNSJ awarded to Eduardo A. Sanabria.

\section{RESUMEN}

La regulación de la temperatura en ectotérmos tiene gran importancia en los procesos fisiológicos y comportamentales. Los cambios en los parámetros térmicos relacionados con la reproducción nos permiten entender de qué manera Rhinella arenarum optimiza el recurso térmico. El objetivo del presente trabajo fue comparar los parámetros térmicos de la especie entre el periodo reproductivo y no reproductivo. En el campo se registraron la temperatura corporal de los animales capturados, la temperatura del aire y del sustrato. Además, en laboratorio se registro la temperatura selecta en un gradiente térmico. Como así también las temperaturas criticas máxima y mínima. Los resultados de nuestro estudio muestran variaciones de los parámetros térmicos entre ambas situaciones estudiadas. Aparentemente esta especie hace un uso eficiente del recurso térmico durante el periodo reproductivo ya que el basking le permite aumentar considerablemente la temperatura corporal, probablemente este comportamiento esté relacionado con el aumento de la eficacia para emitir el canto durante el periodo de reproducción ya que el mismo es energéticamente costoso para los machos.

Palabras clave: Argentina, Rhinella arenarum, Extremos térmicos, Temperatura selecta, Reproducción.

\section{REFERENCES}

Angilletta M.J. Jr., 2009. Thermal adaptation a theoretical and empirical synthesis. Oxford University, New York, USA.

Bee M.A. 2002. Territorial male bullfrogs (Rana catesbeiana) do not assess fighting ability based on size-related variation in acoustic signals. Behav. Ecol. 13:109-124

Brattstrom B.H. \& P. Lawrence. 1962. The rate of thermal acclimation in anuran amphibians. Physiol. Zool. 35: 148-156.

Brattstrom B.H. 1963. Preliminary revision of the thermal requierements of the amphibians. Ecology 44: 238-255.

Bradford D.F. 1984. Temperature modulation in highelevation amphibians, Rana mucosa. Copeia 1984: 966-976.

Brown J.L. 1964. The evolution of diversity in avian territorial systems. Wilson Bull. 76: 160-169.
Duellman W.E. \& L. Trueb. 1986. Biology of amphibians. McGraw-Hill, Baltimore, Maryland, USA.

Fellers G.M. 1979. Aggression, territoriality, and mating behaviour in North American treefrogs. Anim. Behav. 27: 107-119.

Gerhardt H.C. 1994. The evolution of vocalization in frogs and toads. Annu. Rev. Ecol. Syst. 25: 293-324.

Heeden S.E. 1975. Body temperature of the mink frog, Rana septentrionalis Baird. J. Herpetol. 5: 211-212.

Hammer Ø., D.A. T Harper \& P.D. Ryan. 2001. PAST: paleontological statistics software package for education and data analysis. Paleontología Electrónica 4: 9. (http://palaeo-electronica.org/2001_1/past/issue1_01. htm)

Hutchison V.H. 1961. Critical thermal maxima in salamanders. Physiol. Zool. 2, 92-125.

Huey R.B. \& R.D. Stevenson. 1979. Integrating thermal physiology and ecology of ectoterms: a discussion of approaches. Am. Zool. 19: 357-366.

Johnson C.R. 1971. Thermal relations and water balance in the day frog, Taudactylus diurnus, from an Australian rain forest. Aus. J. Zool. 19:35-39.

Light, P., W. Dawson., V. Shoemaker \& A. R. Main. 1966. Observation on the thermal relations of Western Australian Lizards. Copeia 1966: 97-110.

Luddecke H. \& O. R. Sánchez. 2002. Are tropical highland frog calls cold-adapted? The case of the Andean Frog Hyla labialis. Biotropica 34: 281-288.

Marshall, V. T., S. C. Humfeld \& M. A. Bee. 2003. Plasticity of aggressive signaling and its evolution in male spring peepers, Pseudacris crucifer. Anim. Beha. 65: 1223-1234.

Martori R., L. Aun, A. Bierri, C. Rozzi Giménez \& E. Heredia. 2005. Reproducción comparada de tres especies de anuros sintópicos de una localidad del sudoeste de Córdoba. Cuad. Herpetol. 18: 43-59.

Navas C.A. 1996. Thermal dependency of field locomotor and vocal performance of high-elevation anuran in the tropical Andes. J. Herpetol. 30: 478-487.

Pough F., R. Andrews, E. Cadle, M. Crump, A. Zavitzky \& R. Wells. 2001. Energetic and perfomance, 196-227. In Herpetology. Princenton Hall, New Jersey, USA.

Sanabria E.A., L.B. Quiroga \&. J.C. Acosta. 2005a. Patrones de actividad temporal estacional y uso de microhábitat de una población de adultos de Bufo 
arenarum, en los humedales de Zonda, San Juan, Argentina. Bol. Soc. Herpetol. Mex. 13: 61-65.

Sanabria E.A., L.B. Quiroga \&. J.C. Acosta. 2005b. Termorregulación de adultos de Bufo arenarum (Anura: Bufonidae) en diferentes microhábitat en los humedales de Zonda, San Juan, Argentina. Rev. Esp. Herpetol. 19: 127-132.

Schwartz J.J. 2001. Call monitoring and interactive playback systems in the study of acoustic interactions among male anurans, p. 183-204. In M. J. Ryan (ed.). Anuran communication. Smithsonian Institution, Washington DC. , USA.

Schneider H. \& U. Sinsch. 1992. Mating call variation in lake frogs referred to as Rana ridibunda Pallas, 1771. Taxonomic implications. Z. Zool. Syst. Evolutionsforsch. 30: 297-315.

Shoemaker V.H., S.S. Hillman, S.D. Hillyard, D.C. Jackson, L.L. McClanahan,. P.C Withers \& M. L. Wygoda. 1992. Exchange of water, ions, and respiratory gases in terrestrial amphibians. p. 125-150. In W.W. Burggren (ed.) Environmental physiology of the amphibians. University of Chicago, Chicago, USA.

Sinsch U. 1989. Behavioural thermoregulation of the Andean toad (Bufo spinolosus) at high altitudes. Oecologia 80:32-38.
Spight T.M. 1967. Evaporation from toads and water surfaces. Nature 214:835-836.

Tracy R.C. 1976. A model of the dynamic exchange of water and energy between a terrestrial amphibian and its environment. Ecol. Monogr. 46: 293-326.

Tracy R.C., K.A. Christian, M.P. O’Connor \& C. R. Tracy. 1993. Behavioral thermoregulation by Bufo americanus: the importance of the hydric environment. Herpetologica 49: 375-382.

Wells K.D. 1977a. The social behavior of anuran amphibians. Anim. Behav. 25: 666-693.

Wells K.D. 1977b. Territoriality and male mating success in the Green Frog (Rana clamitans). Ecology 58: $750-762$.

Wells K.D. 2001. The energetics of calling in frog, p. 45-60. In M. J. Ryan (ed.). Anuran communication. Smithsonian Institution, Washington, DC. USA.

Zweifel R.G. 1968. Effects of temperature, body size, and hybridization on mating calls of toads, Bufo a. americanus and Bufo woodhousii fowleri. Copeia 1968: 269-285.

Weldon P., B. Demeter \& Rosscoe, R. 1993. A survey of shed skin-eating (Dermatophagy) in amphibians and reptiles. J. Herpetol. 27: 219-228. 